\title{
Effects of high sucrose diet, gemfibrozil, and their combination on plasma paraoxonase 1 activity and lipid levels in rats
}

\author{
Marija Macan1, Nada Vrkić2, Ana Lucić Vrdoljak33, Božica Radić3 and Vlasta Bradamante1凶 \\ 1 University of Zagreb, School of Medicine, Department of Pharmacology, Zagreb, Croatia; 2University of Zagreb, Faculty of Pharmacy and Bio- \\ chemistry, Clinical Institute of Chemistry, and "Sestre milosrdnice" University Hospital, Zagreb, Croatia; ${ }^{3}$ Institute for Medical Research and Oc- \\ cupational Health, Zagreb, Croatia
}

\begin{abstract}
We investigated the influence of high sucrose diet (HSD) after 3 or 5 weeks of administration on paraoxonase 1 (PON1) activity in plasma of normolipidemic rats and the relationship between serum PON1 activity, triacylglycerides (TGs), HDL and total cholesterol vs. the control group of rats fed normal, control diet (CD). Because the data about the influence of gemfibrozil (GEM) on PON1 activity are controversial, we also investigated its effects (administration in the 4th and 5th week in rats on HSD and $C D$ ) on plasma PON1 activity and lipid levels in normolipidemic rats, and in rats with hypertriglyceridemia caused by HSD. Our results obtained in rats on HSD show a significant increase of plasma TGs levels by $47 \%$ $(P<0.05)$ after 5 weeks of treatment, and PON1 activity by $32 \%$ and $23 \%(P<0.05)$ after 3 and 5 weeks, but without change in lipid levels vs. rats on CD. In the rats on CD and HSD, GEM caused a significant decrease of PON1 activity by $44 \%$ and $33 \%$, while a significant decrease of TGs level by $38 \%(P<0.05)$ was measured only in rats on CD. The effects of GEM on total cholesterol, HDL and LDL in both groups of rats were typical for its action on lipoprotein metabolism. Because GEM in the rat liver stimulates proliferation of peroxisomes, $\beta$ oxidation, and production of $\mathrm{H}_{2} \mathrm{O}_{2}$, it is possible that the oxidative stress induced by GEM damages hepatocytes and lowers the synthesis of PON1.
\end{abstract}

Keywords: high sucrose diet, gemfibrozil, paraoxonase, lipids

Received: 11 December, 2009; 14 April, 2010, accepted: 08 June, 2010; available on-line: 11 June, 2010

\section{INTRODUCTION}

Plasma paraoxonase 1 (PON1) (aryldialkylphosphatase, EC 3.1.8.1) is an esterase, synthesized by the liver and secreted into the plasma, where it is associated with highdensity lipoproteins (HDL) and apolipoprotein AI (apo $\mathrm{AI}$ ), the structural peptide of HDL. PON1 secretion is stimulated by HDL, which is also an important factor in the stabilization of the enzyme activity (James \& Deakin, 2004). PON1 received its name from paraoxon, the active metabolite of the organophosphorus insecticide parathion, whose hydrolysis it catalyzes. PON1 also hydrolyses nerve agents (e.g., sarin, soman, VX) and arylesters, and metabolizes a number of drugs and pro-drugs via its lactonase activity (Costa et al., 2005). One natural physiological function of PON1 appears to be the metabolism of toxic oxidized lipids of both low-density lipoproteins (LDL) and HDL particles (Mackness et al., 1996). The results of many studies have shown that PON1 prevents the formation of oxidized LDL, causes the inactivation of LDL-derived oxidized phospholipids once they are formed, and protects phospholipids in HDL from oxidation. Due to these reasons, it is possible that PON1 has a significant role in the prevention of cardiovascular diseases and atherosclerosis (McElveen et al., 1986; Mackness et al., 2006). Two closely related proteins, paraoxonase 2 (PON2) and paraoxonase 3 (PON3), have been identified as well. PON2 is expressed in many tissues, whereas PON3 is also contained in HDL particles. PON2 and PON3 have antioxidant properties, but they have no paraoxon-hydrolyzing activity (Aviram \& Rosenblat, 2005). The most important difference between HDL and LDL lies in the fact that although LDL is the major target for the antioxidant action of PON1, LDL is not associated with PON1, and it is not able to stimulate PON1 secretion. Although the experiments of James et al. (1998) have shown no evidence for the association of PON1 with LDL or very low-density lipoproteins (VLDL), the results of Deakin et al. (2005) have shown that TGs transport vector, VLDL, can modulate PON1 metabolism and activity in vitro, and that this lipoprotein provides an alternative vector to HDL for promoting and sustaining an active, circulating form of PON1. They have also found that serum TGs are positively associated with the whole serum PON1 mass but negatively associated with its specific activity (Deakin et al., 2005).

It is well known that PON1 activity can be modulated by diet (Costa et al., 2005; Soran et al., 2009). So, mice of the B6 strain fed an atherogenic diet for three months showed an approximately $60 \%$ decrease in serum PON1 activity and a similar reduction in liver PON1 mRNA levels. Feeding of both normal New Zealand white rabbits and rabbits transgenic for human apo AI with an atherogenic diet for 14 weeks resulted in a $50 \%$ decrease in serum PON1 activity as well. Kudchodkar et al. (2000) proved that serum PON1 activity was significantly higher in rats fed triolein, lower in those fed fish oil, and unchanged in those fed tripalmitin compared with a control diet. On the other hand, high vegetable intake in humans led to a significantly lower PON1 activity (Kleemola et al., 2002).

e-mail: vbradam@mef.hr

Abbreviations: apo Al, apolipoprotein $\mathrm{Al}$; apo $\mathrm{E}$, apolipoprotein $\mathrm{E}$; CD, control diet; GEM, gemfibrozil; HSD, high sucrose diet; HDL, high-density lipoproteins; LDL, low-density lipoproteins; PON1, paraoxonase 1 ; TGs, triacylglycerides; VLDL, very low-density lipoproteins 
The influence of diet rich in sucrose on PON1 activity is not known. As it is known that diet rich in sucrose increases the synthesis and secretion of VLDL by the liver and induces hypertriglyceridemia in humans and rats (Kannan et al., 1981; Strobl et al., 1989; Saku et al., 1996), our first object was to investigate the influence of HSD on PON1 activity in the plasma of normolipidemic rats and to determine the relationship between serum PON1 activity, TGs, HDL and total cholesterol. GEM, a derivative of fibric acid, is an effective cholesterol- and TGs-lowering agent which has been shown beneficial in the treatment of atherosclerosis. Since the data on the influence of GEM on PON1 activity in animals and humans (Balogh et al., 2001; Beltowski et al., 2002) are controversial, the purpose of this study was to investigate the influence of chronic GEM treatment on plasma PON1 activity and lipids level in normolipidemic rats, and in rats with hypertriglyceridemia caused by HSD.

\section{MATERIAL AND METHODS}

Test substances. Gemfibrozil (CAS-25812-30-0) was obtained from the Pharmaceutical and Chemical Company Lek, Ltd. (Ljubljana, Slovenia), and administered daily into the stomach by oral gavage $(50 \mathrm{mg} / \mathrm{kg}$ body mass per day) in saline. HSD was commercially prepared by ICN (Milan, Italy). This diet contained $68 \%$ (w/w) sucrose, $18 \%$ casein, $8 \%$ cottonseed oil, $2 \%$ brewer's yeast, $4 \%$ salts mix USP II, vitamins and trace elements.

Treatment of animals. Adult male Wistar rats (180-220 g body mass) were fed either normal rat chow CD or HSD. The duration of all experiments was three or five weeks, and all experiments were conducted under identical conditions. The rats were randomised in two control groups ( $\mathrm{n}=7$ each) and four experimental groups ( $\mathrm{n}=7 \mathrm{each})$. The two control groups were given CD for three and five weeks, and two experimental groups were given HSD for three and five weeks. The third and fourth experimental groups were fed CD and HSD for five weeks, together with GEM treatment in the last two weeks (the 4 th and 5th week of study). Following an overnight fast, the rats were killed at 9:00-10:00 h under diethyl ether anaesthesia, and blood plasma was obtained directly from the heart. Plasma samples for measuring PON1 activity were frozen immediately after sampling at $-20{ }^{\circ} \mathrm{C}$ until further processing. Plasma lipids were measured $2-4 \mathrm{~h}$ after sampling. Handling and treatment of the animals were conducted on basis of the international guidelines regarding the use of laboratory animals. The experiments had been approved by the local ethics committee.

PON1 activity. PON1 activity in the plasma was measured using synthetic diethyl- $p$-nitrophenyl phosphate (paraoxon, o,o-diethyl- $p$-nitrophenylphosphate, Sigma Chemical Co., London, UK) and $\mathrm{CaCl}_{2}(1 \mathrm{mM}$ in $0.1 \mathrm{M}$ Tris buffer, $\mathrm{pH}$ 7.4) as moderator. The activity toward paraoxon was determined by measuring the initial rate of substrate hydrolysis to $p$-nitrophenol. In brief, reaction (final volume $1100 \mu \mathrm{l}$ ) for the hydrolysis of paraoxon contained $200 \mu \mathrm{l}$ of $0.1 \mathrm{M}$ Tris buffer (pH 7.4), $\mathrm{CaCl}_{2}$ and $800 \mu \mathrm{l}$ of $1 \mathrm{mM}$ paraoxon solution to which 100 $\mu \mathrm{l}$ undiluted plasma was added to start the reaction. Increase in absorbance at $405 \mathrm{~nm}$ was monitored for 3-5 min. The blank sample containing incubation mixture without plasma was run in parallel to correct for sponta- neous substrate breakdown. The enzyme activity was calculated from $\varepsilon_{405}$ of $p$-nitrophenol $\left(16000 \mathrm{l} \cdot \mathrm{mol}^{-1} \cdot \mathrm{cm}^{-1}\right)$ and was expressed in $\mu \mathrm{mol} \cdot \mathrm{min}^{-1} \cdot \mathrm{ml}^{-1}$ (Beltowski et al., 2004).

Lipids and lipoproteins. Lipids were determined on an Olympus automatic analyser AU 2700 using original reagents produced by Olympus Diagnostics GmbH (Irish Branch, Lismeehan, Ireland). The plasma concentrations of total cholesterol and TGs were determined by enzymatic colorimetric methods (Allain et al., 1974; Shepard \& Whiting, 1990). HDL level was estimated using a compound method of immuno-inhibition with $\beta$-lipoprotein antibody in the first step, and enzymatic colorimetric measuring of accessible cholesterol in the second step (Bachorik, 1991). LDL was calculated mathematically from the concentrations of total cholesterol, TGs and HDL using Friedwald's formula $L D L=$ total cholesterol $-T G s / 2.2-H D L(R e-$ isen, 1998). The approximate formula applies only for plasma without chylomicrons and TGs concentration of less than $4.7 \mathrm{mmol} / 1$. All lipid concentrations were expressed as $\mathrm{mmol} / \mathrm{l}$.

Glucose determination. Plasma concentration of glucose was determined by enzymatic UV test with specific enzyme hexokinase. The test was performed on an automatic Olympus analyser AU 2700 using original reagents produced by Olympus Diagnostics (Czok \& Barthelmai, 1962).

Statistical analysis. Data are shown as the mean \pm standard deviation (S.D.). Descriptive statistics, 95\% confidence intervals and hypothesis testing were made using Statistics ${ }^{\circledR}$ for Windows Version 5.0. The statistical significance was determined by multivariate $t$-test (Hotelling's T test). All applied procedures were 2 -tailed. The differences discussed in this paper were considered significant at the $P \leq 0.05$ level of significance.

\section{RESULTS}

Our results for plasma lipids and glucose in rats treated with HSD, GEM, and their combination had been reported earlier (Bradamante et al., 2005), but in a different context in which we studied whether hypertriglyceridemia increased plasma butyrylcholinesterase activity and whether GEM treatment decreased it. Since we took enough plasma samples for determing the activity of paraoxonase 1 as well, there was no need for new determinations and further animal sacrifice. We used the plasma results of lipids and glucose for the investigation of the relation between PON1 and plasma lipids.

\section{Effects of HSD on plasma PON1 activity and lipids}

There was a significant increase of PON1 activity following both three and five weeks of HSD supplementation compared with rats fed CD (Table 1). In the two treatments the significant increase of enzyme activity was $32 \%$ and $23 \%$ compared with their control values ( $\mathrm{Ta}-$ ble 1). The values of total cholesterol, HDL and LDL did not significantly change after three or five weeks of HSD treatment (Table 1). However, compared with rats fed CD, the TGs level in rats on HSD was higher by $20 \%$ after three weeks of treatment, and significantly higher by $47 \%$ after five weeks of treatment. The plasma glucose level in the rats on HSD was significantly higher only after five weeks of treatment (Table 1) in comparison with the control. 
Table 1. Paraxonase activity, lipids and glucose in plasma of HSD rats Mean \pm S.E.D. are shown.

\begin{tabular}{|c|c|c|c|c|c|c|}
\hline Parameter & $\begin{array}{l}C D^{*} \\
3 \text { weeks }\end{array}$ & $\begin{array}{l}\text { HSD* } \\
3 \text { weeks }\end{array}$ & $\begin{array}{l}P \text { value } \\
3 \text { weeks }\end{array}$ & $\begin{array}{l}C D^{*} \\
5 \text { weeks }\end{array}$ & $\begin{array}{l}\text { HSD* } \\
5 \text { weeks }\end{array}$ & $\begin{array}{l}P \text { value } \\
5 \text { weeks }\end{array}$ \\
\hline $\begin{array}{l}\text { Paraoxonase } \\
\mu \mathrm{mol} / \mathrm{min} \text { per } \mathrm{ml}(\%)\end{array}$ & $\begin{array}{l}0.172 \pm 0.024 \\
(100)\end{array}$ & $\begin{array}{l}0.23 \pm 0.05 \\
(132) \\
(105-160)\end{array}$ & 0.026 & $\begin{array}{l}0.236 \pm 0.025 \\
(100)\end{array}$ & $\begin{array}{l}0.290 \pm 0.048 \\
(123) \\
(101-145)\end{array}$ & 0.045 \\
\hline $\begin{array}{l}\text { Triglycerides*** } \\
\mathrm{mmol} / \mathrm{l}(\%)\end{array}$ & $\begin{array}{l}0.76 \pm 0.12 \\
(100)\end{array}$ & $\begin{array}{l}0.91 \pm 0.31 \\
(120) \\
(84-155)\end{array}$ & 0.248 & $\begin{array}{l}0.81 \pm 0.23 \\
(100)\end{array}$ & $\begin{array}{l}1.19 \pm 0.33 \\
(147) \\
(106-187)\end{array}$ & 0.027 \\
\hline $\begin{array}{l}\text { Total cholesterol** } \\
\mathrm{mmol} / \mathrm{l}(\%)\end{array}$ & $\begin{array}{l}1.55 \pm 0.27 \\
(100)\end{array}$ & $\begin{array}{l}1.44 \pm 0.23 \\
(93) \\
(74-112)\end{array}$ & 0.425 & $\begin{array}{l}1.42 \pm 0.21 \\
(100)\end{array}$ & $\begin{array}{l}1.52 \pm 0.2 \\
(107) \\
(90-123)\end{array}$ & 0.408 \\
\hline $\begin{array}{l}\mathrm{HDL} * * \\
\mathrm{mmol} / \mathrm{l}(\%)\end{array}$ & $\begin{array}{l}0.84 \pm 0.15 \\
(100)\end{array}$ & $\begin{array}{l}0.88 \pm 0.15 \\
(105) \\
(85-125)\end{array}$ & 0.581 & $\begin{array}{l}0.84 \pm 0.11 \\
(100)\end{array}$ & $\begin{array}{l}0.91 \pm 0.13 \\
(108) \\
(91-126)\end{array}$ & 0.298 \\
\hline $\begin{array}{l}\mathrm{LDL}^{* *} \\
\mathrm{mmol} / \mathrm{I}(\%)\end{array}$ & $\begin{array}{l}0.55 \pm 0.13 \\
(100)\end{array}$ & $\begin{array}{l}0.44 \pm 0.09 \\
(80) \\
(56-103)\end{array}$ & 0.087 & $\begin{array}{l}0.39 \pm 0.08 \\
(100)\end{array}$ & $\begin{array}{l}0.40 \pm 0.05 \\
(102) \\
(83-122)\end{array}$ & 0.748 \\
\hline $\begin{array}{l}\text { Glucose*** } \\
\mathrm{mmol} / \mathrm{l}(\%)\end{array}$ & $\begin{array}{l}3.97 \pm 0.59 \\
(100)\end{array}$ & $\begin{array}{l}11.11 \pm 2.59 \\
(280) \\
(225-335)\end{array}$ & $>0.001$ & $\begin{array}{l}5.14 \pm 1.5 \\
(100)\end{array}$ & $\begin{array}{l}10.02 \pm 3.0 \\
(195) \\
(141-249)\end{array}$ & 0.002 \\
\hline
\end{tabular}

$P$ values are results of comparison of HSD vs. CD with multivariate $t$-test. Relative changes $(\%)$ and ranges $(95 \% \mathrm{Cl})$ are given in brackets. ${ }^{*} \mathrm{CD}$, control diet; HSD, high sucrose diet; ${ }^{* *}$ Results for plasma lipids and glucose were taken from Bradamante et al. (2005).

\section{Effects of GEM on plasma PON1 activity and lipids in the rats on $C D$ and HSD}

In the normolipidemic rats on $\mathrm{CD}$ or in rats fed with HSD, the addition of GEM in the 4th and 5th weeks of the study caused a significant decrease of PON1 activity by $44 \%$ and $33 \%$ in comparison with rats on $C D$ and HSD, but without GEM treatment (Table 2). The addition of GEM to the group of normolipidemic rats on CD in the 4th and 5th weeks of study caused a significant increase $(P<0.05)$ of total cholesterol and HDL by $33 \%$ and $44 \%$, and a significant decrease of TGs level by $38 \%(P<0.05)$, while the value of LDL was unchanged in comparison with the control (Table 2). In rats fed HSD, the administration of GEM caused a significant increase of total cholesterol, HDL and LDL by $36 \%, 44 \%$ and $20 \%(P<0.05)$, while TGs level was unchanged $v$ s. the control (Table 2).

\section{DISCUSSION}

HSD causes an increase of serum TGs level and dyslipidemia as a consequence of sucrose hydrolysis into its constituents - glucose and fructose, and their conversion into TGs (Diniz et al., 2006; Bar-On \& Stein, 1994; Kannan et al., 1981). In this process, a few facts are important: (1) the conversion rate of fructose into lipids in the liver and the TGs secretion rate is greater than that of glucose (Kannan et al., 1981; Bar-On \& Stein, 1994), (2) fructose administration does not stimulate the lipoprotein lipase release, and (3) the inflow of fatty acids into the liver from adipose tissue is not depressed (Kannan et al., 1981; Bar-On \& Stein, 1994). Due to these reasons, our results obtained in rats that showed a significant increase of plasma TGs levels by $47 \%(P<0.05$,

Table 2. Effect of GEM on paraxonase activity, lipids and glucose in plasma of rat

Rats were fed CD or HSD for 5 weeks. GEM was added in the 4th and 5th week. Mean \pm S.E.D. are shown.

\begin{tabular}{|c|c|c|c|c|c|c|}
\hline Parameter & $C D^{*}$ & $\mathrm{CD}^{*}+\mathrm{GEM}^{* * *}$ & $P$ value & $\mathrm{HSD}^{*}$ & $\mathrm{HSD}^{*}+\mathrm{GEM}^{* * *}$ & $P$ value \\
\hline $\begin{array}{l}\text { Paraoxonase } \\
\mu \mathrm{mol} / \mathrm{min} \text { per } \mathrm{ml}(\%)\end{array}$ & $\begin{array}{l}0.236 \pm 0.025 \\
(100)\end{array}$ & $\begin{array}{l}0.131 \pm 0.022 \\
(56) \\
(42-69)\end{array}$ & 0.001 & $\begin{array}{l}0.290 \pm 0.048 \\
(100)\end{array}$ & $\begin{array}{l}0.196 \pm 0.019 \\
(67) \\
(52-83)\end{array}$ & 0.001 \\
\hline $\begin{array}{l}\text { Triglycerides** } \\
\mathrm{mmol} / \mathrm{l}(\%)\end{array}$ & $\begin{array}{l}0.81 \pm 0.23 \\
(100)\end{array}$ & $\begin{array}{l}0.50 \pm 0.12 \\
(62) \\
(33-90)\end{array}$ & 0.013 & $\begin{array}{l}1.19 \pm 0.33 \\
(100)\end{array}$ & $\begin{array}{l}1.17 \pm 0.43 \\
(98) \\
(59-136)\end{array}$ & 0.899 \\
\hline $\begin{array}{l}\text { Total cholesterol** } \\
\mathrm{mmol} / \mathrm{l}(\%)\end{array}$ & $\begin{array}{l}1.42 \pm 0.21 \\
(100)\end{array}$ & $\begin{array}{l}1.89 \pm 0.34 \\
(133) \\
(109-156)\end{array}$ & 0.012 & $\begin{array}{l}1.52 \pm 0.2 \\
(100)\end{array}$ & $\begin{array}{l}2.11 \pm 0.33 \\
(136) \\
(120-153)\end{array}$ & 0.001 \\
\hline $\begin{array}{l}\mathrm{HDL}^{* *} \\
\mathrm{mmol} / \mathrm{l}(\%)\end{array}$ & $\begin{array}{l}0.84 \pm 0.11 \\
(100)\end{array}$ & $\begin{array}{l}1.21 \pm 0.27 \\
(144) \\
(115-173)\end{array}$ & 0.007 & $\begin{array}{l}0.91 \pm 0.13 \\
(100)\end{array}$ & $\begin{array}{l}1.30 \pm 0.25 \\
(144) \\
(124-162)\end{array}$ & 0.001 \\
\hline $\begin{array}{l}\mathrm{LDL}^{* *} \\
\mathrm{mmol} / \mathrm{I}(\%)\end{array}$ & $\begin{array}{l}0.39 \pm 0.08 \\
(100)\end{array}$ & $\begin{array}{l}0.37 \pm 0.07 \\
(95) \\
(72-118)\end{array}$ & 0.659 & $\begin{array}{l}0.40 \pm 0.05 \\
(100)\end{array}$ & $\begin{array}{l}0.48 \pm 0.06 \\
(120) \\
(105-135)\end{array}$ & 0.016 \\
\hline $\begin{array}{l}\text { Glucose*** } \\
\mathrm{mmol} / \mathrm{l}(\%)\end{array}$ & $\begin{array}{l}5.14 \pm 1.5 \\
(100)\end{array}$ & $\begin{array}{l}6.65 \pm 2.15 \\
(129) \\
(86-173)\end{array}$ & 0.166 & $\begin{array}{l}10.02 \pm 3.0 \\
(100)\end{array}$ & $\begin{array}{l}8.64 \pm 2.27 \\
(86) \\
(51-122)\end{array}$ & 0.405 \\
\hline
\end{tabular}

$P$ values are results of comparison of CD + GEM vs. CD and HSD + GEM vs. HSD with multivariate $t$-test. Relative changes (\%) and ranges $(95 \% \mathrm{Cl})$ are given in brackets. ${ }^{*} \mathrm{CD}$, control diet; $\mathrm{HSD}$, high sucrose diet; ${ }^{*}$ Results for plasma lipids and glucose were taken from Bradamante et al. (2005); ***GEM, gemfibrozil. 
Table 1) after five weeks of HSD treatment, could be predicted. The effect of HSD on TGs level was correlated positively with the treatment duration (Table 1).

Various in vivo studies in animals and humans have provided evidence that HSD induces hyperlipidemia and oxidative stress (Diniz et al., 2006; Busserolles et al., 2002a; 2002b) and that these conditions per se negatively modulate the PON1 activity (Durrington et al., 2001). It has also been found that HSD decreases the activity of superoxide dismutase (Beltowski et al., 2000) and increases plasma concentration of thiobarbituric acid-reactive substances (Beltowski et al., 2000; Busserolles et al., 2002a). Considering that consumption of HSD negatively modulates the PON1 activity, we expected a decrease of its activity. Our results have shown however, that in comparison with control groups, HSD treatment for three or five weeks causes hypertriglyceridemia (significant after five weeks) and a significant increase of PON1 activity by $32 \%$ and $23 \%$ (Table 1), while the level of HDL is unchanged. This positive association between HSD, hypertriglyceridemia and higher PON1 activities obtained in our results can be partially explained by the results of Deakin et al. (2005) who examined the influence of VLDL on PON1 secretion. In those in vitro experiments, they showed that VLDL promoted the secretion of PON1 from a transfected Chinese hamster ovary model and from transfected hepatocytes in a high-affinity, saturable manner. They also showed that low levels of active PON1 were associated with VLDL in the human serum, and that the VLDL-associated PON1 activity was proportional to plasma TGs concentrations. Although Deakin et al. (2005) found that serum TGs were positively associated with the whole serum PON1 mass but negatively with the specific enzyme activity, we suppose that the positive association between serum TGs concentrations, PON1 activity and HDL, noticeable in our results, was a direct consequence of the experimental conditions in vivo. Based on the results of Beltowski et al. (2000), Busserolles et al. (2002a) and Deakin et al. (2005), we think that the positive influence of HSD on plasma PON1 activity found in our experiments is a result of higher level of TGs caused by HSD, that overcame the possible oxidant effect of HSD on the enzyme activity. Our results are backed up by the results of experiments in rats fed different diet, that differently influenced the activity of antioxidant enzymes. High-calorie high-fat and high-calorie normal-fat diet decreased the activity of superoxide dismutase but increased that of glutathione peroxidase in rats (Beltowski et al., 2000). We also suggest that higher PON1 activity can insure further protection of both HDL and VLDL from oxidation.

The addition of GEM to the group of normolipidemic rats on CD in the 4th and 5th weeks of study caused a significant decrease of TGs level (Table 2). This result was expected from the mechanism of action of GEM and other fibrates on metabolism of TGs, and is confirmed in numerous studies in animals (Dashti \& Ontko, 1983; Petit et al., 1988; Ozansoy et al., 2001) and humans (Yoshida et al., 1998; Balogh et al., 2001; Chen et al., 2001). On the other hand, the addition of GEM to the group of rats on HSD did not cause any change in TGs level (Table 2). We suggest that the stimulatory effect of HSD on TGs synthesis in the liver is much stronger than the known inhibitory action of GEM on the plasma TGs level. The addition of GEM to the group of normolipidemic rats on $\mathrm{CD}$, or to the group of rats on HSD caused in the both groups a significant increase of total cholesterol and HDL vs. their control groups (Ta- ble 2). Although the positive influence of GEM on total cholesterol and HDL obtained in our results could be predicted and is congruent with the results of other authors (Krause \& Newton, 1986; Krause et al., 1996), it is important to mention that the data about the influence of GEM and other fibrates on lipoprotein metabolism are not unequivocal. Thus, the total, free cholesterol and HDL were decreased in male rats after treatment with clofibrate for seven days in doses of $0.5 \mathrm{mmol} / \mathrm{kg}$ (Dashti \& Ontko, 1983), while HDL in cholesterol-fed rats was increased by GEM 3.6-fold, by fenofibrate 1.3fold and by ciprofibrate 1.2 -fold, but not by clofibrate, when dosed per os at $50 \mathrm{mg} / \mathrm{kg}$ for two weeks (Krause \& Newton, 1986; Krause et al., 1996). GEM was also a significant and major determinant of elevated apolipoprotein $\mathrm{E}$ (apo $\mathrm{E}$ ) and apo $\mathrm{AI}$, while bezafibrate produced opposite effects, a decrease of HDL, apo $E$ and liver TGs, and tended to increase LDL as well (Krause \& Newton, 1986; Krause et al., 1996). Since apo AI and apo $\mathrm{E}$ are the major HDL peptides in the rat, it was concluded that GEM, which produces a rise in the serum concentrations of both apo $\mathrm{AI}$ and apo E, and enhances the hepatic synthesis and secretion of apo E, produces the greatest elevations of HDL as well (Krause \& Newton, 1986). We also suggest that the increase of HDL, obtained in our results, is a consequence of the increased synthesis of apo $\mathrm{E}$ in the liver. The mechanism that is responsible for the effects of GEM on lipoprotein metabolism is not known in details, but recent studies have shown that many of the above effects of GEM and other fibrates are mediated by their interaction with peroxisome proliferator-activated receptor $\alpha(\operatorname{PPAR} \alpha)$ (Steals et al., 1992). Although rodents are more susceptible to peroxisome proliferators than are dogs, rhesus monkeys or humans, there is no evidence yet that GEM and fibrates are exogenous ligands for PPAR receptors.

The present study has shown that GEM treatment causes opposite effects on HDL level and PON1 activity. After GEM treatment, plasma HDL was significantly higher and PON1 activity significantly lower in the rats on CD and HSD (Table 2) in comparison with the values from rats on CD or on HSD diet but without GEM treatment (Table 2). Plasma PON1 is located on HDL, and drugs, such as GEM and other fibrates, which increase HDL, might therefore increase the enzyme activity as well. This relationship was shown by Balogh et al. (2001), who demonstrated that twice-daily administration of $600 \mathrm{mg}$ of GEM for three months in type-2 diabetic patients caused an increase of serum PON1 activity and HDL level. Similar results, i.e. increased PON1 activity and HDL level were obtained in patients with coronary heart disease, who were treated with micronised fenofibrate for three months (Paragh et al., 2003). In another case, bezafibrate (400 $\mathrm{mg}$ daily) and GEM (600 $\mathrm{mg}$ twice daily) administered in patients with type IIb hyperlipoproteinemia for eight weeks significantly reduced the serum TGs concentration and increased HDL without an effect on the PON1 activity (Durrington et al., 1998). It was concluded that although both the PON1 concentration and its activity are correlated with the level of serum HDL and apo AI, the strength of these correlations is not high and it is therefore likely that in their physiological concentration ranges the levels of PON1 and other HDL components can fluctuate independently (Durrington et al., 1998). In contrast to the above results, Beltowski et al. (2002) found that in normolipidemic rats fenofibrate treatment decreased plasma level of lipid peroxidation products without changing the total plasma 
antioxidant capacity, TGs or cholesterol concentrations, but it caused a significant dose-dependent decrease of plasma PON1 activity by $20 \%$ to $40 \%$. It was suggested that this effect of fenofibrate on PON1 activity would be potentially its adverse effect, which could be masked by beneficial changes in the plasma lipid profile (Beltowski et al., 2002). Our results have confirmed this presumption.

It is known that GEM has both antioxidant and prooxidant actions and that it influences the oxidant status. First, it was proved that GEM together with its metabolite M1 may show antioxidant properties in vitro (Yoshida et al., 1998; Aviram et al., 1998; Kawamura et al., 2000) and in vivo (Ozansoy et al., 2001; Chen et al., 2001) on LDL, VLDL, and HDL oxidation, which could be related to their free radical scavenging activity, as well as to their metal ion chelation capacities. Second, the opposite evidence can be found in some other data. Thus, Scatena et al. (1997) have shown that a single oral therapeutic dose of GEM, acting as a primer, in human volunteers significantly enhances the induced reactiveoxygen-species production by overall blood phagocytes, polymorphonuclear leukocytes and monocytes, when these cells are stimulated by phorbol myristate acetate. Consequently, the enhancing effect of GEM on the reactive oxygen metabolism of leukocytes represents a possibility of damage at the level of different cells and tissues. GEM also showed its oxidative effects on anion influx and metabolism in normal and $\beta$-thalassemic erythrocytes (Tellone et al., 2008). Taking into consideration the results of Scatena et al. (1997) and Tellone et al. (2008) mentioned above, and the negative influence of fenofibrate and GEM on PON1 activity that was seen in the results of Beltowski et al. (2002), and in the our results as well, we think that the significant decrease of PON1 activity in our results is primarily a consequence of the oxidant action of GEM. At the molecular level, it is known that GEM, like other fibrates, induces marked proliferation of PPAR $\alpha$ in rats (Arnaiz et al., 1995), and peroxisomal $\beta$ oxidation of fatty acids, which is the main source of PPAR $\alpha$-mediated reactive hydrogen peroxide $\left(\mathrm{H}_{2} \mathrm{O}_{2}\right)$ production. Because PPAR $\alpha$ in rodents is expressed primarily in the liver, and to a lesser extent in kidney, heart and skeletal muscles, it is possible that the oxidative stress induced by GEM damages the hepatocytes and hampers the synthesis of PON1. Our results regarding the concentrations of malonyldialdehyde and PON1 activity in the plasma and other tissues of rats treated with GEM have supported this hypothesis about its strong prooxidant activity (unpublished). On the other hand, examination of human liver biopsy material, obtained from patients receiving GEM or other fibrates, has demonstrated marginal or no increase in peroxisomal volume, densities or number (Lock et al., 1989). Due to these reasons, it is very likely that the different effect of GEM on PON1 activity in humans and in rats is a consequence of the evident species differences in the sensitivity to fibrates.

In the present study GEM treatment has caused a small but significant increase of LDL in rats fed HSD (Table 2). A similar medical report was described in hypertriglyceridemic patients, who were frequently found to have incomplete VLDL to LDL conversion before treatment (Kissebah et al., 1981). Because the plasma cholesterol in rats is essentially represented by HDL, we suggest that this increase of LDL in rats is without any importance. In contrast, in patients with hypertriglyceri- demia, the increase of LDL caused by GEM has shown a possible atherogenic effect of GEM treatment.

In conclusion, the results of our study have clearly demonstrated that HSD increases the plasma TGs level and the activity of PON1 in rats without changing the total cholesterol, HDL and LDL. Because HSD did not per se negatively modulate the PON1 activity, we think that the significant increase of PON1 activity was mainly due to the direct influence of higher level of TGs caused by HSD, which promoted higher secretion of PON1 from hepatocytes. In rats on $\mathrm{CD}$ and HSD, GEM caused a significant decrease of PON1 activity and a significant increase of total cholesterol and HDL $v s$, the controls, while TGs level was significantly decreased only in the rats on normal diet. Because GEM in the liver of rats stimulates strongly the proliferation of peroxisomes, $\beta$ oxidation, and production of $\mathrm{H}_{2} \mathrm{O}_{2}$, it is possible that the oxidative stress induced by GEM is a cause of damage of hepatocytes and leads to decreased synthesis of PON1.

In view of these results further studies of the influence of different types of diet and GEM on the oxidant status and antioxidant enzymes are clearly needed.

\section{Acknowledgements}

This study was supported by the Ministry of Science, Education and Sports of the Republic of Croatia. We gratefully acknowledge the expert technical assistance of Mrs Željka Roca.

\section{REFERENCES}

Allain CC, Poon LS, Chang CSG, Riomond W, Fu PC (1974) Enzymatic determination of total serum cholesterol. Clin Chem 20: $470-$ 475.

Arnaiz SL, Travacio M, Llesuy S, Boveris A (1995) Hydrogen peroxide metabolism during peroxisome proliferation by fenofibrate. Biochem Biophys Acta 1272: 175-180.

Aviram M, Rosenblat M (2005) Paraoxonases and cardiovascular diseases: pharmacological and nutritional influences. Curr Opin Lipidol 16: 393-399.

Aviram M, Rosenblat M, Bisgaier CL, Newton RS, Primo-Parmo SL, La Du BN (1998) Paraoxonase inhibits high-density lipoprotein oxidation and preserves its function: a possible peroxidative role for paraoxonase. J Clin Invest 101: 1581-1590.

Bachorik PS (1991) Measurement of low density lipoprotein cholesterol. In Handbook of lipoprotein testing. Rifai N, Warnic RG, Dominiczok $\mathrm{H}$ eds, pp 145-160. AACC Press, Washington.

Balogh Z, Seres I, Harangi M, Kovács P, Kakuk Gy, Paragh Gy (2001) Gemfibrozil increases paraoxonase activity in type 2 diabetic patients. A new hypothesis of the beneficial action of fibrates? Diabetes Metab 27: 604-610.

Bar-On H, Stein Y (1994) Effect of glucose and fructose administration on lipid metabolism in the rat. J Nutrition 94: 95-105.

Beltowski J, Wójcicka G, Górny D, Marciniak A (2000) The effect of dietary-induced obesity on lipid peroxidation, antioxidant enzymes and total plasma antioxidant capacity. J Physiol Pharmacol 51: 883896.

Beltowski J, Wójcicka G, Mydlarczyk M, Jamroz A (2002) The effect of peroxisome proliferator-activated receptors alpha (PPARalpha) agonist, fenofibrate, on lipid peroxidation, total antioxidant capacity, and plasma paraoxonase 1 (PON 1) activity. J Physiol Pharmacol 53: $463-475$.

Beltowski J, Wojcicka G, Jamroz A (2004) Effect of 3-hydroxy-3methyl-glutaryl coenzyme A reductase inhibitors (statins) on tissue paraoxonase 1 and plasma platelet activating factor acetylhydrolase activities. J Cardiovasc Pharmacol 43: 121-127.

Bradamante V, Vrkić N, Lucić A, Macan M (2005) Interrelated effects of high sucrose diet and gemfibrozil on butyrylcholinesterase activity and plasma lipids in rats. Period Biol 107: 189-193.

Busserolles J, Rock E, Gueux E, Mazur A, Grolier P, Rayssiguier Y (2002a) Short-term consumption of a high-sucrose diet has a prooxidant effect in rats. Br J Nutr 87: 337-342. 
Busserolles J, Zimowska W, Rock E, Rayssiguier Y, Nazur A (2002b) Rats fed a high sucrose diet have altered heart antioxidant enzyme activity and gene expression. Life Sci 71: 1303-1312.

Chen MF, Wang TD, Yeh HT, Hsu HC, Lee YT (2001) Gemfibrozil treatment potentiates oxidative resistance of high-density lipoprotein in hypertriacylglyceridemic patients. Eur J Clin Invest 31: 707-713.

Czok R, Barthelmai W (1962) Enzymatische Bestimmungen der Glucose in Blut, Liquor und Ham. Klin Wschr 40: 585-589.

Costa LG, Vitalone A, Cole TB, Furlong CE (2005) Modulation of paraoxonase (PON1) activity. Biochem Pharmacol 69: 541-550.

Dashti N, Ontko JA (1983) Alterations in rat serum lipids and apolipoproteins following clofibrate treatment. Atherosclerosis 49: 255-266.

Deakin S, Moren X, James RW (2005) Very low density lipoproteins provide a vector for secretion of paraoxonase-1 from cells. Atherosclerosis 179: 17-25.

Diniz YS, Rocha KKHR, Souza GA, Galhardi CM, Ebaid GMX, Rodrigues HG, Novelli Filho JLVB, Cicogna AC, Novelli ELB (2006) Effects of $N$-acetylcysteine on sucrose-rich diet-induced hyperglycaemia, dyslipidemia and oxidative stress in rats. Eur J Pharmacol 543: 151-157.

Durrington PN, Mackness MI, Bhatnagar D, Julier K, Prais H, Arrol S, Morgan J, Wood GNI (1998) Effects of two different fibric acid derivatives on lipoproteins, cholesterol ester transfer, fibrinogen, plasminogen activator inhibitor and paraoxonase activity in type IIb hyperlipoproteinemia. Atherosclerosis 138: 217-225.

Durrington PN, Mackness B, Mackness MI (2001) Paraoxonase and atherosclerosis. Arterioscler Thromb V asc Biol 21: 473-480.

James RW, Deakin SP (2004) The importance of high-density lipoproteins for paraoxonase-1 secretion, stability, and activity. Free Radic Biol Med 37: 1986-1994.

James RW, Blatter Garin MC, Calabresi L, Miccoli R, von Eckardstein A, Tilly-Kiesi M, Taskinen MR, Assmann G, Franceschini G (1998) Modulated serum activities and concentrations of paraoxonase in high density lipoprotein deficiency states. Atherosclerosis 139: 77-82.

Kannan R, Baker N, Bruckdorfer KR (1981) Secretion and turnover of very low density lipoprotein triacylglycerols in rats fed chronically diets rich in glucose and fructose. J Nutr 111: 1216-1223.

Kawamura M, Miyazaki S, Teramoto T, Ashidate K, Thoda H, Ando N, Kaneko K (2000) Gemfibrozil metabolite inhibits in vitro lowdensity lipoprotein (LDL) oxidation and diminishes cytotoxicity induced by oxidized LDL. Metabolism 49: 479-485.

Kissebah AH, Alfarsi S, Adams PW (1981) Integrated regulation of very low density lipoprotein triacylglyceride and apolipoprotein-B kinetics in man: normolipidemic subjects, familial hypertriacylglyceridemia and familial combined hyperlipidemia. Metabolism 30: 856868.

Kleemola P, Freese R, Jauhiainen M, Pahlman R, Alfthan G, Mutanen M (2002) Dietary determinants of serum paraoxonase activity in healthy humans. Atherosclerosis 160: 425-432.

Krause BR, Newton RS (1986) Gemfibrozil increases both apoA-I and apo $\mathrm{E}$ concentrations. Comparison to the other lipid regulators in cholesterol-fed rats. Atherosclerosis 59: 95-98.

Krause BR, Barnett BC, Essenburg AD, Kieft KA, Auerbach BJ, Bousley R, Stanfield R, Newton RS, Bisgaier CL (1996) Opposite effects of bezafibrate and gemfibrozil in both non and hypertriacylglyceridemic rats. Atherosclerosis 127: 91-101.

Kudchodkar BJ, Lacko AG, Dory L, Fungwe TV (2000) Dietary fat modulates serum paraoxonase 1 activity in rats. $J$ Nutr 130: 24272433.
Lock EA, Mitchell AM, Elcombe CR (1989) Biochemical mechanisms of induction of hepatic peroxisome proliferation. Annu Rev Pharmacol Toxicol 29: 145-163.

Mackness MI, Mackness B, Durrington PN, Connelly PW, Hegele RA (1996) Paraoxonase: biochemistry, genetics and relationship to plasma lipoproteins. Curr Opin Lipidol 7: 69-76.

Mackness B, Hine D, McElduff P, Mackness M (2006) High C-reactive protein and low paraoxonase 1 in diabetes as risk factors for coronary heart disease. Atherosclerosis 186: 396-401.

McElveen J, Mackness MI, Colley CM, Peard T, Warner S, Walker CH (1986) Distribution of paraoxon hydrolytic activity in the serum of patients after myocardial infarction. Clin Chem 32: 671-673.

Ozansoy G, Akin B, Aktan F, Karasu Ç (2001) Short-term gemfibrozil treatment reverses lipid profile and peroxidation but does not alter blood glucose and tissue antioxidant enzymes in chronically diabetic rats. Mol Cell Biochem 216: 59-63.

Paragh G, Seres I, Harangi M, Balogh Z, Illyés L, Boda J, Szilvássy Z, Kovács P (2003) The effect of micronised fenofibrate on paraoxonase activity in patients with coronary heart disease. Diabetes Metab 29: 613-618.

Petit D, Bonnefis MT, Rey C, Infante R (1988) Effects of ciprofibrate and fenofibrate on liver lipids and lipoprotein synthesis in normoand hyperlipidemic rats. Atherosclerosis 74: 215-225.

Reisen WF (1998) Lipid metabolism. In Clinical laboratory diagnostics. Use and assessements of clinical laboratory results; pp 169-172. TH-books Verlasgesellschaft, Frankfurt/Main.

Saku K, Okamoto T, Takeda Y, Jimi S, Zhang B, Bai H, Liu R, Arakawa K (1996) Short-term effects of a high-sucrose diet on plasma lipid, lipoprotein cholesterol, tissue lipoprotein lipase and hepatic triacylglyceride lipase in rats. Artery 22: 36-48.

Scatena R, Nocca G, De Sole P, Fresu R, Zuppi C, Giardina B (1997) The priming effect of gemfibrozil on reactive oxygen metabolism of phagocytic leucocytes. An intriguing side effect. Clin Chim Acta 226: $173-183$.

Shephard MDS, Whiting MJ (1990) Falsely low estimation of triacylglycerides in lipemic plasma by the enzymatic triglyceride method with modified Trinder's chromogen. Clin Chem 36: 325-329.

Soran H, Younis NN, Charlton-Menys V, Durrington P (2009) Variation in paraoxonase-1 activity and atherosclerosis. Curr Opin Lipidol 20: $265-274$.

Staels B, van Tol A, Andreu T, Auwerx J (1992) Fibrates influence the expression of genes involved in lipoprotein metabolism in a tissueselective manner in the rat. Arterioscler Thromb V asc Biol 12: 286-294.

Strobl W, Gorder NL, Fienup GA, Lin-Lee Y-C, Gotto AM, Patsch W Jr (1989) Effect of sucrose diet on apolipoprotein biosynthesis in rat liver. Increase in apolipoprotein $\mathrm{E}$ gene transcription. J Biol Chem 264: 1190-1194.

Tellone E, Ficarra S, Giardiana B, Scatena R, Russo A, Clementi ME, Misiti F, Bellocco E, Galtieri A (2008) Oxidative effects of gemfibrozil on anion influx and metabolism in normal and beta-thalassemic erythrocytes: physiological implications. J Memb Biol 224: $1-8$.

Yoshida H, Ishikawa T, Ayaori M, Shige H, Ito T, Suzukawa M, Nakamura H (1998) Beneficial effect of gemfibrozil on the chemical composition and oxidative susceptibility of low density lipoprotein: a tandomized, double-blind, placebo-controlled study. Atherosclerosis 139: 179-187. 